\title{
IDENTIFIKASI SEBARAN KERENTANAN KEKERINGAN PERTANIAN MENGGUNAKAN ANALYTICAL HIERARCHY PROCESS (AHP) DI KABUPATEN TEMANGGUNG
}

\author{
IDENTIFICATION OF AGRICULTURAL DROUGHT DISTRIBUTION USING \\ ANALYTICAL HIERARCHY PROCESS (AHP) IN TEMANGGUNG REGENCY
}

\author{
${ }^{* 1}$ Ikaf Fajar Maulana, Sudaryanto', dan Retnadi Heru Jatmiko \\ Penginderaan Jauh, Fakultas Geografi, Universitas Gadjah Mada, Yogyakarta.
}

Submitted:03-02-2020; Revised:28-10-2020; Accepted: 15-06-2021

\begin{abstract}
The decreased rainfall in Indonesia is mainly influenced by the east monsoon so air pressure from the southern hemisphere which is dry will flow through Indonesia. In a relatively long time, this may cause drought condition on agricultural land in Indonesia in general and in Temanggung Regency in particular. In addition, ENSO (El Nino Southern Oscillation) contributed to the decreased rainfall in Indonesia. This phenomenon will be more intensive and extreme with the existence of global warming. The identification of vulnerability of agricultural drought is an effort to mitigate disasters. This study aims to determine the distribution of agricultural drought and determine the factors that influence agricultural drought in Temangung Regency. The research method used the Analytical Hierarchy Process (AHP) to build a model of agricultural drought vulnerability by considering several factors. The results showed that the area of agricultural land which is vulnerable and very vulnerable to drought is $86,2 \mathrm{~km}^{2}$ and 74,14 $\mathrm{km}^{2}$, while agricultural land with moderate vulnerability is $208,21 \mathrm{~km}^{2}$, and agricultural land which is not vulnerable and very not vulnerable to drought is $128,15 \mathrm{~km}^{2}$ and $267,33 \mathrm{~km}^{2}$. The main factor as a determinant of agricultural drought in Temanggung Regency is rainfall. Meanwhile, the next factor is the respective land cover and soil texture. This research concludes that the effect of slope is not a big impact on agricultural drought in Temanggung Regency.
\end{abstract}

Keywords: Agricultural drought; Analytical hierarchy process (AHP); Disaster mitigation; Geographic information system (GIS); Remote sensing.

\section{ABSTRAK}

Penurunan curah hujan di Indonesia utamanya dipengaruhi oleh muson timur sehingga tekanan udara dari belahan bumi selatan yang sifatnya kering melewati Indonesia. Dalam waktu yang relatif lama hal ini akan menimbulkan dampak kekeringan pada lahan pertanian di Indonesia pada umumnya dan di Kabupaten Temanggung pada khususnya. Selain itu, adanya ENSO (El Nino Southern Oscillation) turut berkontribusi terhadap penurunan curah hujan di Indonesia. Fenomena ini akan lebih intensif dan ekstrem karena terjadinya pemanasan global. Identifikasi kerentanan kekeringan pertanian merupakan upaya untuk mitigasi bencana. Penelitian ini bertujuan untuk mengetahui sebaran kekeringan pertanian dan mengetahui faktor yang mempengaruhi kekeringan pertanian di Kabupaten Temanggung. Metode penelitian yang dipergunakan yaitu Analytical Hierarchy Process (AHP) untuk membangun model kerentanan kekeringan pertanian dengan mempertimbangkan beberapa faktor. Hasil penelitian menunjukkan bahwa luasan lahan

*Corresponding author: ikaf.fajar@gmail.com

Copyright @2021 THE AUTHOR(S).This article is distributed under a Creative Commons Attribution-Share Alike 4.0 International license. Jurnal Teknosains is published by the Graduate School of Universitas Gadjah Mada. 
pertanian yang rentan dan sangat rentan terhadap kekeringan yaitu $86,2 \mathrm{~km}^{2}$ dan $74,14 \mathrm{~km}^{2}$ sedangkan lahan pertanian dengan kerentanan sedang seluas $208,21 \mathrm{~km}^{2}$ dan lahan pertanian yang tidak rentan dan sangat tidak rentan terhadap kekeringan yaitu sebesar $128,15 \mathrm{~km}^{2}$ dan $267,33 \mathrm{~km}^{2}$. Faktor utama sebagai penentu kekeringan pertanian di Kabupaten Temanggung yakni curah hujan. Sementara itu, faktor selanjutnya yaitu masingmasing penutup lahan dan tekstur tanah. Penelitian ini menyimpulkan bahwa kemiringan lereng pengaruhnya tidak besar terhadap kekeringan pertanian di Kabupaten Temanggung.

Kata Kunci: Analytical hierarchy process (AHP); Kekeringan pertanian; Mitigasi bencana; Penginderaan jauh; Sistem informasi geografi (SIG).

\section{PENGANTAR}

Kekeringan merupakan suatu kondisi ketika ketersediaan air tidak mampu mencukupi kebutuhan akan air sehingga terjadi defisit air. Fenomena ini terjadi ketika terjadi penurunan curah hujan dalam waktu yang relatif lama. Indonesia merupakan wilayah yang paling rentan terjadi kekeringan karena dipengaruhi oleh beberapa faktor. Faktor utama yang mendorong kekeringan di Indonesia adalah ketika posisi matahari terletak di belahan bumi utara. Posisi matahari menyebabkan pergerakan udara dari belahan bumi bagian selatan menuju bagian utara karena perbedaan tekanan udara. Udara yang berasal dari belahan bumi bagian selatan memiliki sifat kering atau tidak mengandung uap air karena udara tersebut bergerak melewati gurun di Australia dan laut yang sempit sehingga Indonesia mengalami musim kemarau (Arnoldussen, 2013).

Faktor lain yang menyebabkan kekeringan di Indonesia yakni El Nino Southern Oscilliation (ENSO). ENSO terjadi ketika suhu di Samudera Pasifik bagian timur dan tengah mengalami peningkatan sehingga bagian tersebut bertekanan udara rendah. Hal ini berbeda dengan Indonesia yang bertekanan tinggi karena dipengaruhi oleh muson timur. Perbedaan tekanan udara antara Indonesia dan Samudera Pasifik menyebabkan awan yang mengandung uap air di Indonesia bergerak ke Samudera Pasifik yang memiliki tekanan udara yang lebih rendah. Fenomena ini menyebabkan Indonesia mengalami penurunan curah hujan (Arjasakusuma et al, 2018). ENSO akan lebih ekstrem dan intensif seiring adanya perubahan iklim yang disebabkan oleh pemanasan global karena akan meningkatan suhu di permukaan bumi (Riphah, 2015). Penurunan curah hujan yang drastis akan menyebabkan kekeringan di Indonesia salah satunya di Pulau Jawa. Pulau Jawa merupakan pulau yang paling rentan terhadap kekeringan, pada tahun 2008 sampai 2018 terdapat 510 kejadian kekeringan atau $55,1 \%$ terjadi di Pulau Jawa (Badan Nasional Penanggulangan Bencana, 2018).

Penurunan curah hujan terjadi di beberapa wilayah di Pulau Jawa salah satunya di Kabupaten Temanggung. Dampak yang ditimbulkan dari penurunan curah hujan yakni terdapat beberapa lahan pertanian yang mengalami kekeringan. Lahan pertanian yang terletak di Gunung Sumbing dan Sindoro mengalami kekeringan karena suplai dari berbagai sumber air mengalami penurunan. Penurunan suplai untuk lahan pertanian mengakibatkan beberapa tanaman mengalami kerusakan karena kekurangan air. Selain itu, terdapat beberapa kecamatan di Kabupaten Temanggung mengantisipasi puso dengan menanam tanaman yang berkebutuhan air sedikit seperti tembakau maupun palawija.

Identifikasi kekeringan pertanian perlu dilakukan untuk meminimalisir dampak yang ditimbulkan atau sebagai upaya untuk mitigasi bencana. Identifikasi kekeringan pertanian perlu mempertimbangkan aspek-aspek yang mempengaruhinya (Mannocchi, 2004). Oleh karenanya, penelitianini melakukan pemodelan kerentanan kekeringan pertanian di Kabupaten Temanggung dengan menggunakan metode Analytical Hierarchy Process (AHP). Tujuan dari penelitian ini yakni untuk mengetahui sebaran kekeringan pertanian dan mengetahui faktor yang mempengaruhi kekeringan pertanian di Kabupaten Temanggung.

\section{Metode \\ Lokasi Penelitian}

Penelitian ini dilakukan di wilayah Kabupaten Temanggung yang berada di 


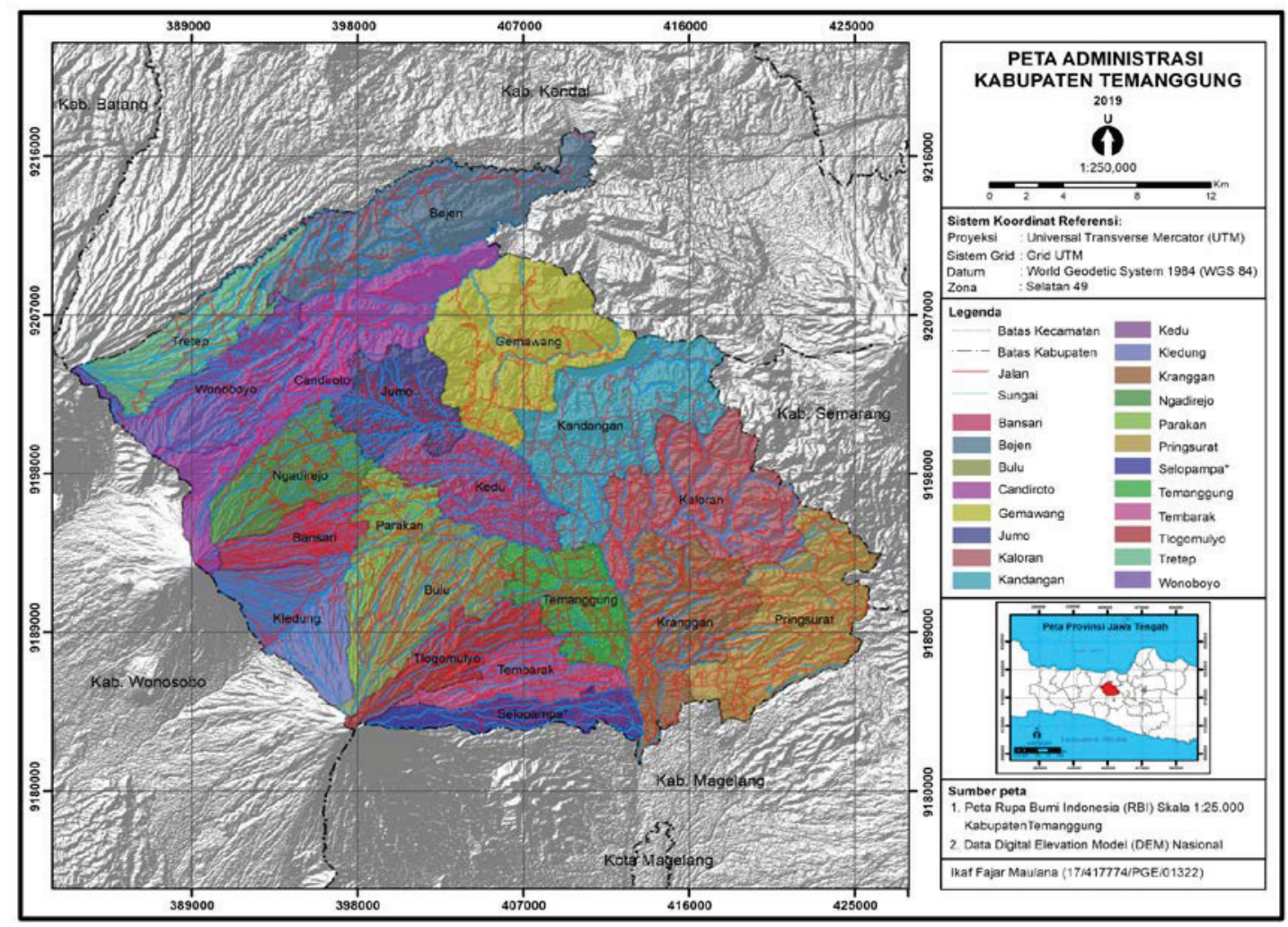

Gambar 1

Lokasi penelitian Kabupaten Temanggung

Sumber: Hasil Pengolahan Citra Digital (2019)

Provinsi Jawa Tengah. Kabupaten Temanggung secara astronomis terletak pada $7^{\circ} 14^{\prime}-7^{\circ} 32^{\prime} 35^{\prime \prime}$ Lintang Selatan dan $110^{\circ} 23^{\prime}-110^{\circ} 46^{\prime} 30^{\prime \prime}$ Bujur Timur. Ditinjau dari sisi geografis, Kabupaten Temanggung berbatasan dengan Kabupaten Kendal, Kabupaten Semarang, Magelang, dan Wonosobo. Kabupaten Temanggung terdiri dari 20 kecamatan dengan 23 kelurahan dan 255 desa (Gambar 1) (Badan Pusat Statistik, 2018).

\section{Alat dan Bahan}

Alat yang digunakan yakni laptop sebagai media pengerjaan dan pemrosesan, ENVI untuk pemrosesan citra penginderaan jauh, ArcGIS untuk pengolahan data spasial, Microsoft Excel sebagai pengolah data penelitian, Expert Choice untuk pengambilan keputusan metode AHP, Global Positioning System (GPS) untuk pencatat titik koordinat di lapangan. Bahan yang digunakan antara lain citra Landsat 8 tanggal perekaman 28 Agustus tahun 2019, Digital Elevation Model (DEM) Nasional, peta geologi lembar Magelang dan Semarang, Jawa tahun 1975, peta rupa bumi Indonesia, serta data curah hujan bulanan dari beberapa pos hujan tahun 2009-2018 di Kabupaten Temanggung dan sekitarnya.

\section{Tahap pengolahan}

Pengolahan peta curah hujan

Informasi curah hujan diturunkan dari data curah hujan bulanan beberapa pos hujan Kabupaten Temanggung dan sekitarnya tahun 2009-2018 menggunakan analisis interpolasi IDW (Inverse Distance Weighting) pada ArcGIS sehingga menghasilkan peta curah hujan.

\section{Pengolahan peta kemiringan lereng}

Informasi terkait kemiringan lereng diturunkan dari data DEM (Digital elevation model) Nasional dengan analisis slope pada 
ArcGIS. Data DEM Nasional yang telah dianalisis slope menghasilkan data kemiringan lereng dengan satuan derajat atau persen dengan mengacu pada klasifikasi kemiringan lereng.

\section{Pengolahan peta penutup lahan}

Informasi terkait penutup lahan diturunkan dari citra Landsat 8 dengan mempertimbangkan sembilan kunci interpretasi seperti rona, warna, tekstur, bentuk, ukuran, pola, situs, asosiasi, dan konvergensi bukti. Klasifikasi penutup lahan yang digunakan yakni klasifikasi penutup lahan menurut SNI 7645: 2014.

\section{Pengolahan bentuk lahan}

Informasi terkait bentuk lahan diturunkan dari informasi seperti kemiringan lereng, pola aliran sungai, geologi/ batuan, penutup lahan, serta komposit citra Landsat 8. Pengenalan karakteristik setiap bentuk lahan perlu mengenali beberapa aspek penting dalam geomorfologi seperti morfografi, morfogenetik, dan morfometri. Klasifikasi bentuk lahan yang digunakan dalam penelitian ini yakni klasifikasi bentuk lahan menurut Zuidam (1983).

\section{Pengolahan peta tekstur tanah}

Informasi tekstur tanah diperoleh dari hasil interpretasi visual pada citra penginderaan jauh dengan mempertimbangkan unsur-unsur yang berkaitan. Unsur-unsur yang dipertimbangkan antara lain bentuk lahan, kemiringan lereng, pola aliran sungai, geologi/ batuan, penutup lahan, serta komposit citra Landsat 8.

\section{Penentuan sampel}

Penentuan pengambilan sampel pada penelitian ini berdasarkan karakteristik geografi di daerah penelitian atau stratified random sampling. Prinsip ini didasari bahwasanya setiap karakteristik geografi memiliki karakter yang berbeda-beda sehingga setiap sampel mewakili setiap karakteristik geografi di daerah penelitian.

\section{Tahap lapangan}

Tahap lapangan merupakan tahapan untuk mengumpulkan data lapangan sebagai data referensi pengujian peta hasil pengolahan. Data yang diperoleh dari tahap lapangan antara lain data tekstur tanah, kemiringan lereng, dan penutup lahan. Data tekstur tanah diperoleh dengan metode kualitatif dan kuantitatif. Selain tekstur tanah, data kemiringan lereng diperoleh dengan menggunakan Abney level. Data penutup lahan diperoleh dari survei di lapangan untuk mengetahui kondisi secara aktual.

\section{Uji akurasi}

Tahap uji akurasi dilakukan untuk mengetahui tingkat kesesuaian peta pengolahan dengan kondisi di lapangan. Uji akurasi untuk menghasilkan informasi tingkat akurasi peta pengolahan dalam satuan persen. Peta yang diuji akurasinya antara lain adalah peta penutup lahan, kemiringan lereng, bentuk lahan, dan tekstur tanah.

\section{Pembobotan}

Pembobotan dilakukan dengan metode Analytical Hierarchy Process (AHP), Analytical hierarchy process (AHP) merupakan metode yang dikemukakan oleh Thomas L, Saaty untuk menentukan suatu keputusan berdasarkan pertimbangan kriteria-kriteria. Penentuan keputusan dibangun dari susunan kriteria-kriteria yang memiliki integrasi secara langsung terhadap suatu keputusan yang akan dicapai (Saaty, 1987). Pada penelitian ini, keputusan yang akan dicapai yakni penentuan kerentanan kekeringan pertanian berdasarkan aspek curah hujan, tekstur tanah, kemiringan lereng, dan penutup lahan. Penentuan nilai dari setiap kriteria untuk mencapai informasi terkait kerentanan kekeringan pertanian diperoleh dari kuisioner pada Badan Penanggulangan Bencana Daerah (BPBD) Kabupaten Temanggung tahun 2020. 


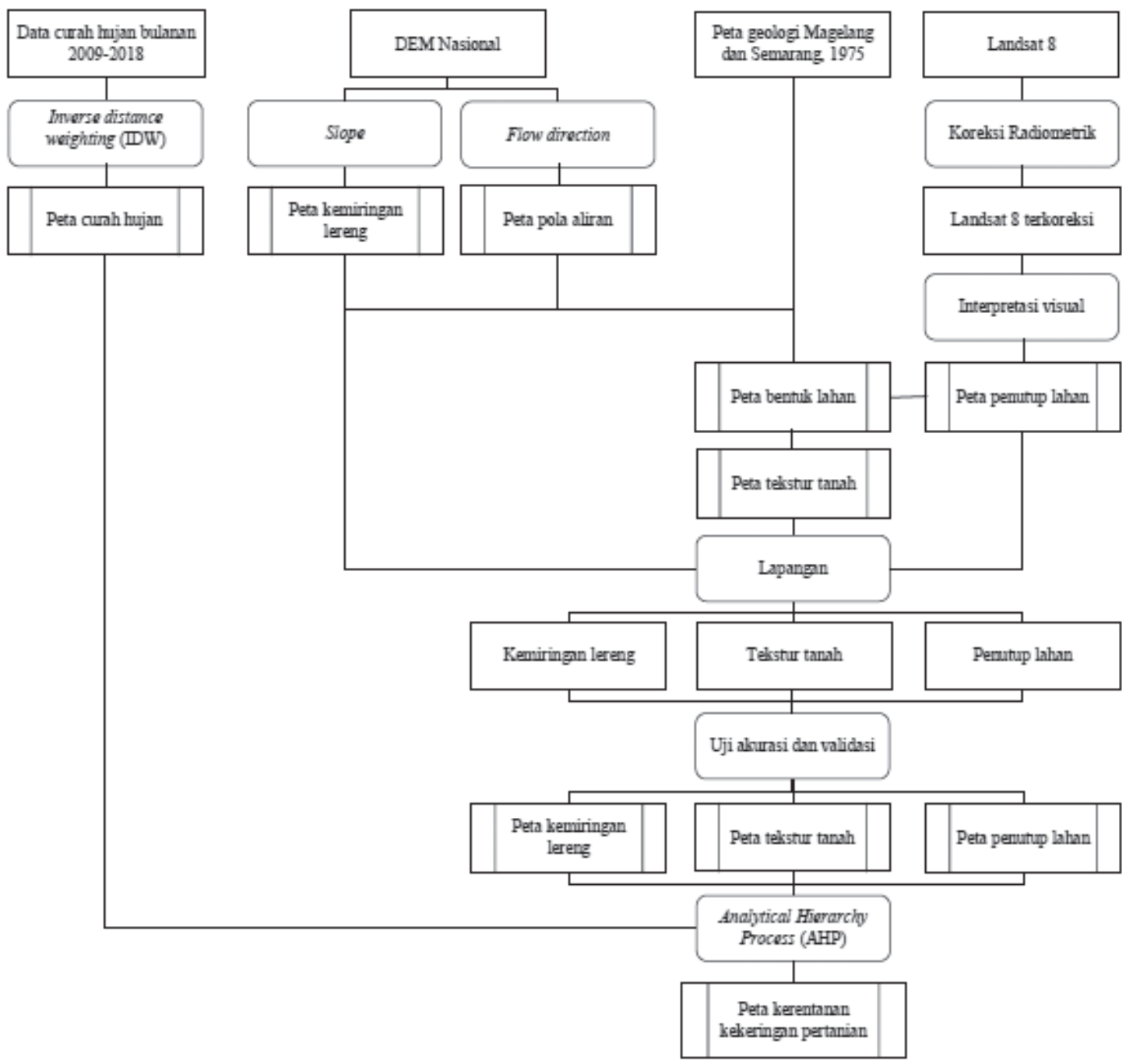

Gambar 2

Diagram alir penelitian

Sumber: Hasil analisis dan pengolahan (2019)

HASIL DAN PEMBAHASAN

\section{Faktor kekeringan pertanian}

Peta curah hujan

Informasi terkait curah hujan diturunkan dari data curah hujan bulanan 2009-2018. Data curah hujan bulanan diperoleh dari beberapa pos hujan Badan Meteorologi dan Klimatologi Geofisika (BMKG) di Kabupaten Temanggung dan sekitarnya. Informasi curah hujan secara spasial diturunkan dengan menggunakan metode interpolasi IDW (Inverse Distance Weighted). Hasil interpolasi menghasilkan informasi terkait rata-rata curah hujan musim penghujan dan kemarau. Rata-rata curah hujan pada musim penghujan di Kabupaten Temanggung sebagian besar dalam kategori tinggi yakni 300-400 mm/bulan. Pada musim kemarau Kabupaten Temanggung memiliki 2 kategori rata-rata curah hujan dalam dengan nilai sebesar 100-150 dan 150-200 mm/bulan. Beberapa kecamatan memiliki rata-rata curah hujan sebesar 100-150 mm/bulan seperti Bejen, Kaloran, Pringsurat, Kranggan, Temanggung, Selopampa, Tembarak, Tlogomulyo, Bulu, Parakan, Kledung, Bansari, dan Ngadirejo, sedangkan beberapa kecamatan memiliki ratarata curah hujan sebesar $150-200 \mathrm{~mm} /$ bulan seperti Tretep, Wonoboyo, Candiroto, Jumo, Kedu, Kandangan, dan Gemawang (Gambar 3) 


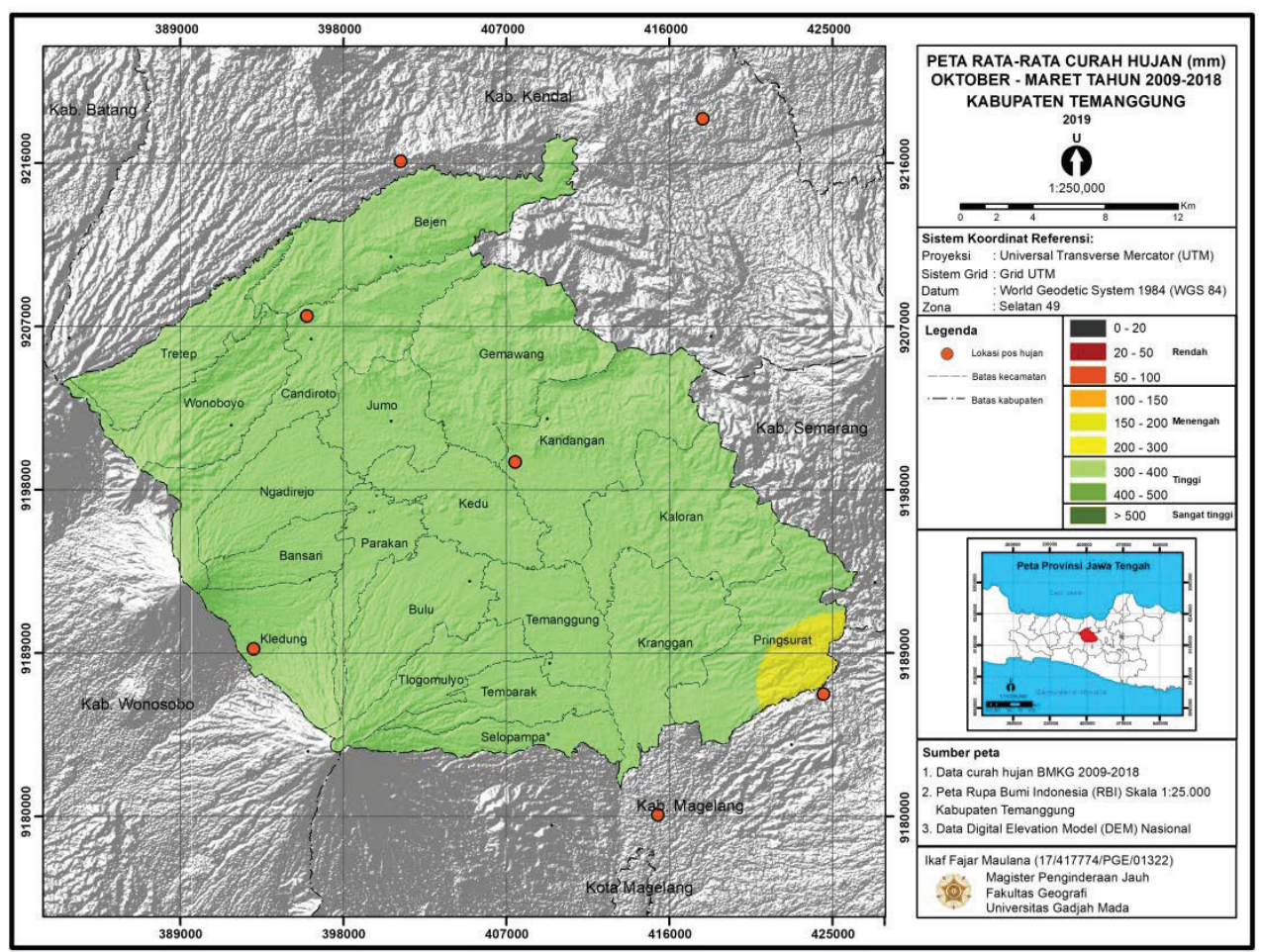

Gambar 3

Peta rata-rata curah hujan pada musim penghujan Kabupaten Temanggung tahun 2009-2018 Sumber: Hasil Pengolahan Citra Digital (2019).

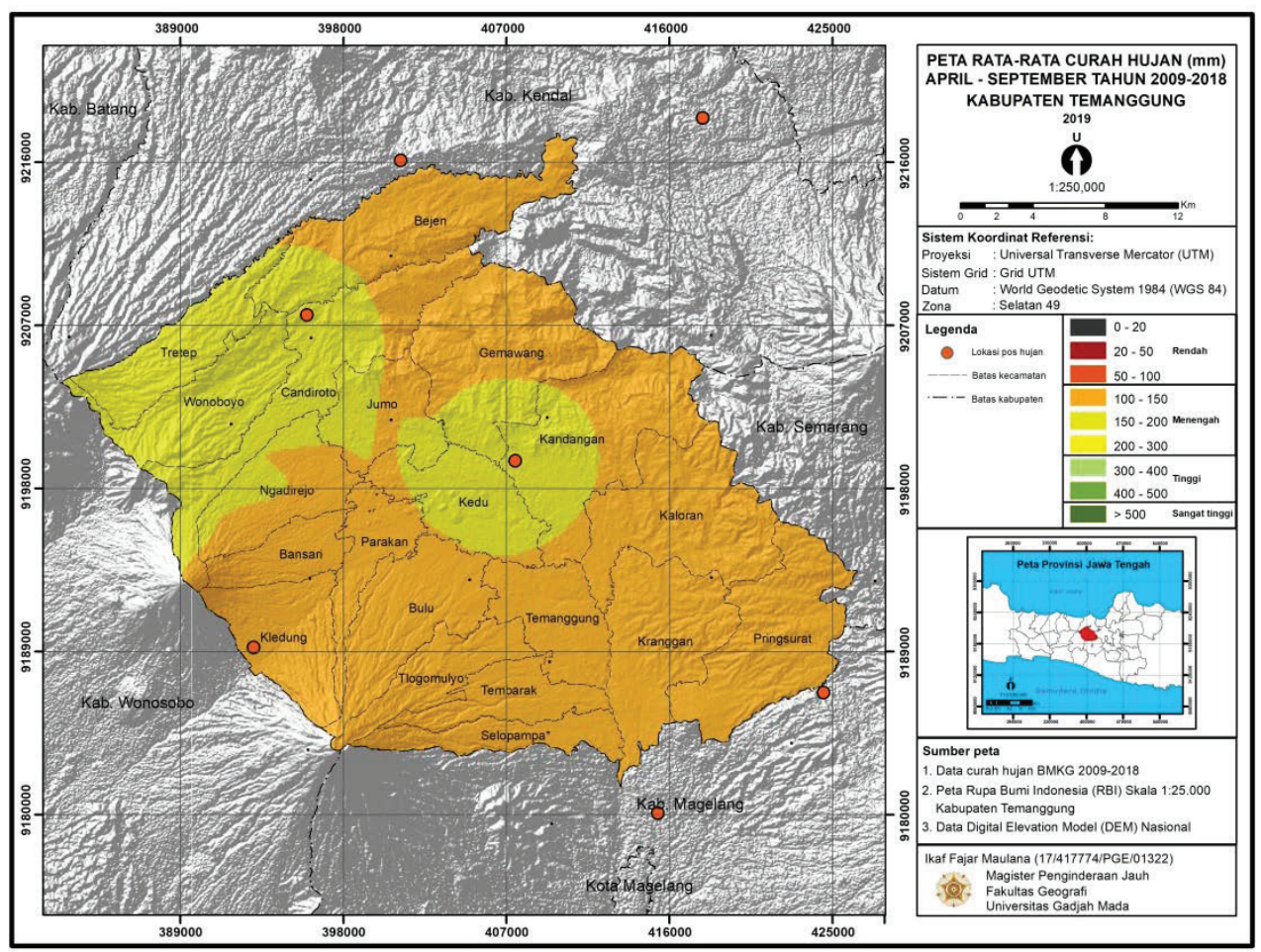

Gambar 4

Peta rata-rata curah hujan pada musim kemarau Kabupaten Temanggung tahun 2009-2018 Sumber: Hasil Pengolahan Citra Digital (2019) 


\section{Peta kemiringan lereng}

Informasi terkait kemiringan lereng diturunkan dari data DEM Nasional. Informasi terkait kemiringan lereng diturunkan dari analisis slope pada ArcGIS sehingga menghasilkan kemiringan lereng dalam satuan persen. Informasi terkait kemiringan lereng dari analisis slope dilakukan uji akurasi dengan perbandingan data lapangan. Data lapangan terkait kemiringan lereng diperoleh dengan alat pengukur kemiringan lereng yakni Abney level. Hasil akurasi peta kemiringan dari analisis slope menghasilkan akurasi sebesar 77,36\%.

Hasil analisis slope pada data DEM Nasional dapat diketahui bahwasanya Kabupaten Temanggung sebagian besar terletak pada kemiringan lereng landai. Luas wilayah yang memiliki kemiringan landai di Kabupaten Temanggung sebesar $267,5 \mathrm{~km}^{2}$ yang sebagian besar terletak pada bagian tengah Kabupaten Temanggung. Selain itu, Kabupaten didominasi pada kemiringan kategori datar dengan luas sebesar 260,52 km². Kemiringan lereng yang mendominasi ketiga di Kabupaten Temanggung yakni lereng agak curam dengan luas sebesar $229,06 \mathrm{~km}^{2}$ yang sebagian besar terletak pada bagian barat dan timur Kabupaten Temanggung, sedangkan kemiringan lereng sangat curam merupakan kemiringan lereng yang memiliki luas terendah di Kabupaten Temanggung dengan luas sebesar 10,18 km² (Tabel 1).

Tabel 1

Luas kemiringan lereng Kabupaten Temanggung tahun 2019

\begin{tabular}{l|l|l|l}
\hline No & Kemiringan lereng & \multicolumn{1}{|c|}{ Luas $\left.\mathbf{( k m}^{\mathbf{2}}\right)$} & Prosentase (\%) \\
\hline 1 & Datar $(0-8 \%)$ & 260,52 & 30,14 \\
\hline 2 & Landai $(8-15 \%)$ & 267,5 & 30,95 \\
\hline 3 & Agak curam $(15-25 \%)$ & 229,06 & 26,5 \\
\hline 4 & Curam (25-40\%) & 97,08 & 11,23 \\
\hline 5 & Sangat curam $(>40 \%)$ & 10,18 & 1,18 \\
\hline \multicolumn{2}{l}{ Total } & 864,34 & 100 \\
\hline
\end{tabular}

Sumber: Hasil pengolahan citra Landsat 8

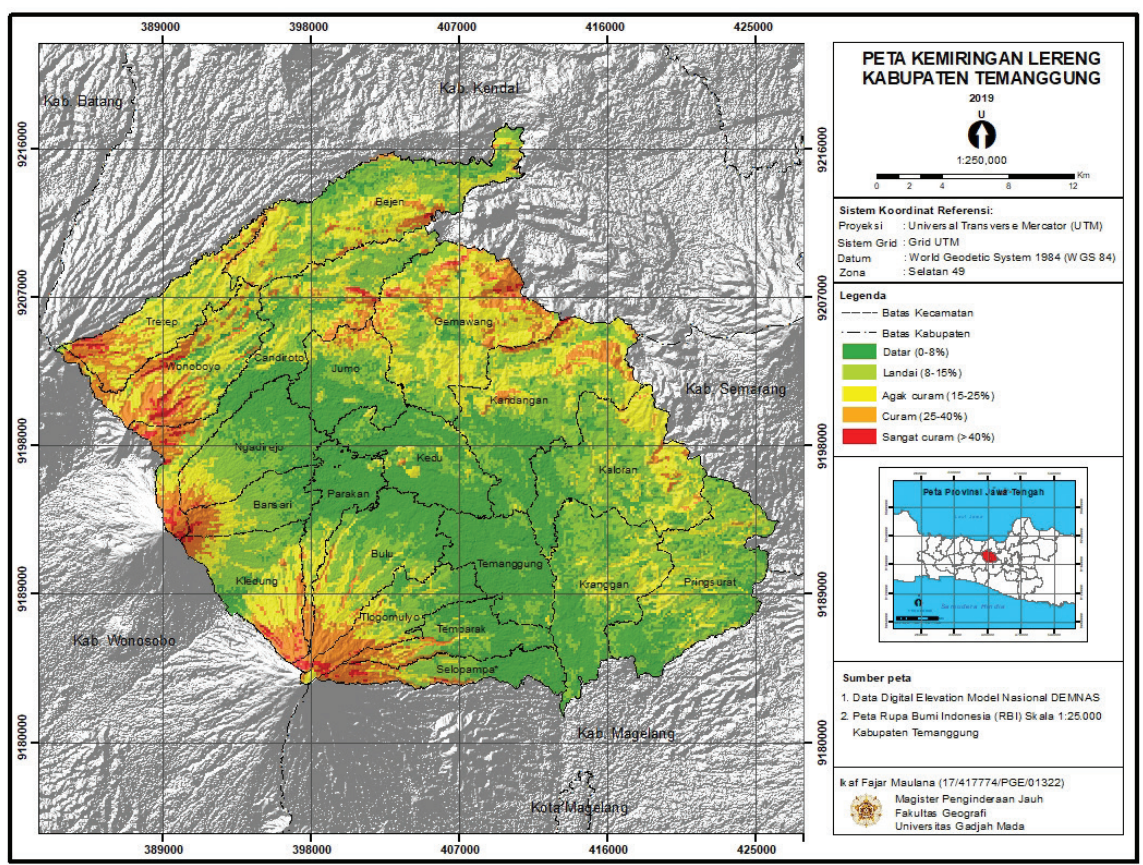

Gambar 5

Peta kemiringan lereng Kabupaten Temanggung tahun 2019

Sumber: Hasil Pengolahan Citra Digital (2019) 


\section{Peta penutup lahan}

Peta penutup lahan diperoleh dari citra Landsat 8 dengan menggunakan metode interpretasi visual. Hasil interpretasi penutup lahan dari citra Landsat 8 disesuaikan dengan kondisi penutup lahan di lapangan untuk mengetahui keakurasian peta penutup lahan hasil interpretasi. Akurasi peta penutup lahan hasil interpretasi memiliki nilai akurasi keseluruhan sebesar $81,98 \%$ yang menunjukkan bahwasanya peta penutup lahan hasil interpretasi merepresentasikan kondisi aktual di lapangan.

Hasil interpretasi visual penutup lahan khusus pertanian di Kabupaten Temanggung mayoritas adalah kebun dan tanaman campuran dengan persentase sebesar $43,32 \%$ atau luas 374 , $45 \mathrm{~km}^{2}$. Sebaran kebun dan tanaman campuran dapat ditemukan di beberapa kecamatan seperti Kecamatan Bejen, Candiroto, Jumo, Gemawang, Kandangan, Kaloran, Kranggan, dan Pringsurat. Penutup lahan dengan persentase terbesar kedua yakni tanaman semusim lahan basah dengan persentase sebesar $27,89 \%$ atau luas sebesar $241,08 \mathrm{~km}^{2}$. Tanaman semusim lahan basah sebagian besar terletak pada bagian tengah Kabupaten Temanggung. Penutup lahan dengan persentase terbesar ketiga yakni tanaman semusim lahan kering dengan persentase sebesar $16,79 \%$ atau luas sebesar 145,11 $\mathrm{km}^{2}$. Penutup lahan tanaman semusim lahan kering terletak pada bagian barat Kabupaten Temanggung tepatnya di lereng Gunung Sumbing dan Sindoro. Penutup lahan pertanian dengan persentase terendah yakni perkebunan kayu keras dengan persentase sebesar $0,39 \%$ atau luas sebesar 3,39 $\mathrm{km}^{2}$ (Tabel 2).

Tabel 2

Luas penutup lahan Kabupaten Temanggung tahun 2019

\begin{tabular}{llll}
\hline No & Penutup lahan & Luas $\left.\mathbf{( k m}^{\mathbf{2}}\right)$ & Persentase \\
\hline 1 & $\begin{array}{l}\text { Tanaman } \\
\text { semusim lahan } \\
\text { kering }\end{array}$ & 145,11 & 16,79 \\
\hline 2 & $\begin{array}{l}\text { Tanaman } \\
\text { semusim lahan } \\
\text { basah }\end{array}$ & & \\
\hline
\end{tabular}

\begin{tabular}{llll}
\hline No & Penutup lahan & Luas $\left.\mathbf{( k m}^{2}\right)$ & Persentase \\
\hline 3 & $\begin{array}{l}\text { Hamparan } \\
\text { batuan/ pasir } \\
\text { alami }\end{array}$ & 7,69 & 0,89 \\
\hline 4 & $\begin{array}{l}\text { Hutan lahan } \\
\text { tinggi }\end{array}$ & 39,13 & 4,53 \\
\hline 5 & $\begin{array}{l}\text { Kebun dan } \\
\text { tanaman } \\
\text { campuran }\end{array}$ & 374,45 & 43,32 \\
\hline 6 & $\begin{array}{l}\text { Bangunan } \\
\text { pemukiman/ } \\
\text { campuran }\end{array}$ & 52,34 & 6,06 \\
\hline 7 & $\begin{array}{l}\text { Perkebunan } \\
\text { tanaman kayu } \\
\text { keras }\end{array}$ & 3,39 & 0,39 \\
\hline 8 & $\begin{array}{l}\text { Lahan terbuka } \\
\text { diusahakan }\end{array}$ & 1,15 & 0,13 \\
\hline & Total & 864,34 & 100 \\
\hline & lot
\end{tabular}

Sumber: Hasil pengolahan citra Landsat 8

\section{Peta bentuk lahan}

Informasi terkait bentuk lahan diperlukan sebagai dasar untuk penentuan tekstur tanah daerah penelitian. Informasi bentuk lahan diturunkan dengan analisis interpretasi visual dengan mempertimbangkan aspek-aspek geomorfologi seperti morfografi, morfogenetik, dan morfometri. Beberapa aspek tersebut diperoleh dari data penginderaan jauh seperti peta geologi, kemiringan lereng, pola aliran sungai, penutup lahan, dan komposit citra Landsat 8. Hasil pengolahan peta bentuk lahan dari interpretasi visual memiliki tingkat akurasi sebesar 82,31\%. Hasil ini diperoleh dari penyesuaian dengan peta geologi lembar Magelang dan Semarang, Jawa tahun 1975. Penyesuaian ini berdasarkan kondisi permukaan bumi berkaitan erat dengan kondisi geologi.

Bentuk lahan di Kabupaten Temanggung didominasi oleh bentuk lahan kaki gunung api dengan persentase sebesar 30,6\% atau luas $264,2 \mathrm{~km}^{2}$. Bentuk lahan lereng tengahatas gunung api merupakan bentuk lahan yang memiliki persentase terbesar kedua di Kabupaten Temanggung dengan luas sebesar 205,38 $\mathrm{km}^{2}$. Selain itu, bentuk lahan dengan persentase terbesar ketiga yakni padang 


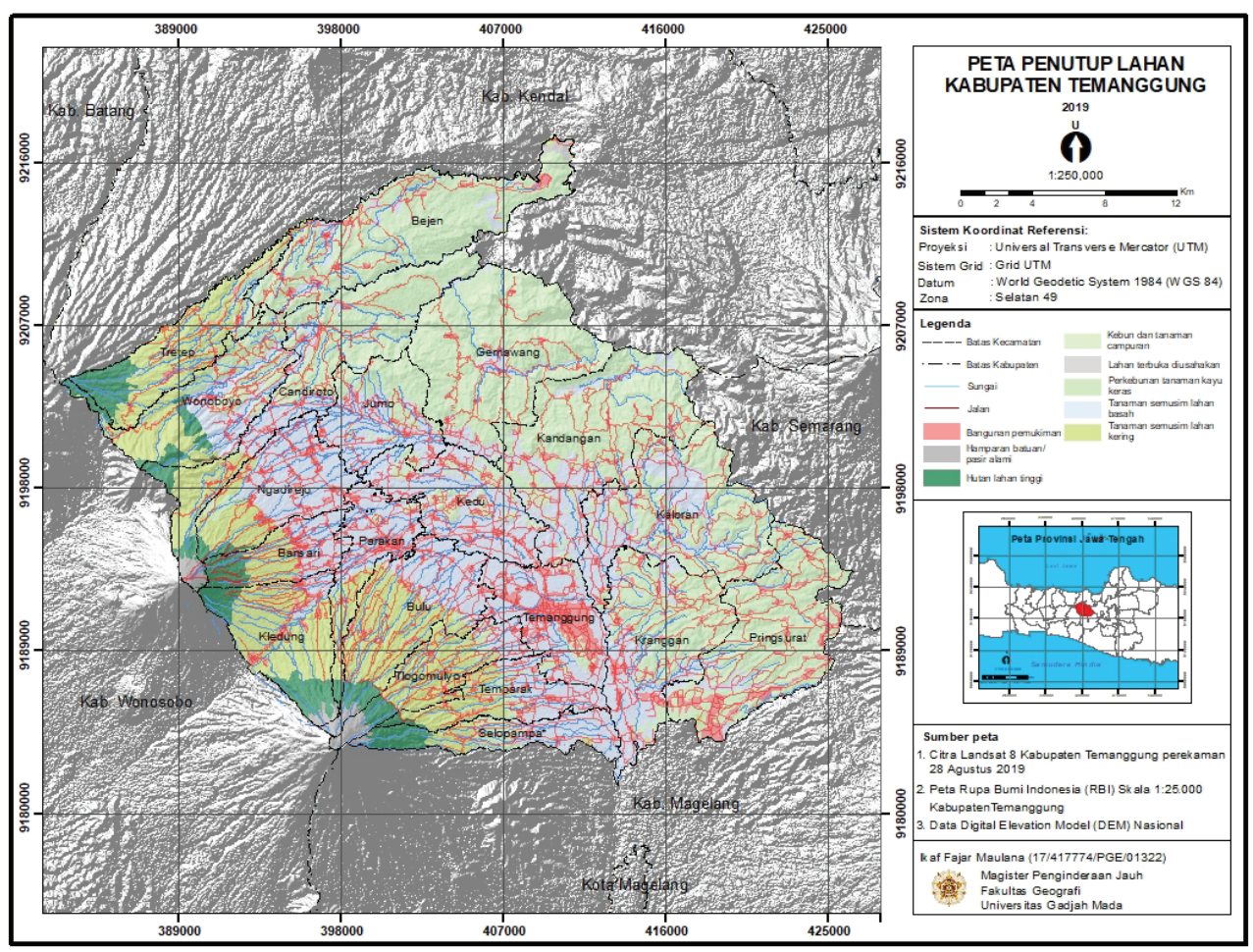

Gambar 6

Peta penutup lahan Kabupaten Temanggung tahun 2019

Sumber: Hasil Pengolahan Citra Digital (2019)

lahar dengan luas sebesar 182,36 $\mathrm{km}^{2}$ (Tabel 3). Bentuk lahan di Kabupaten Temanggung mayoritas merupakan bentuk lahan asal vulkanik. Hal ini memiliki keterkaitan secara langsung dengan pertemuan lempeng antara Eurasia dan India-Australia. Pertemuan kedua lempeng ini menyebabkan lahirnya dapur magma baru karena gaya gesek dari kedua lempeng tersebut sehingga menimbulkan pertumbuhan gunung api (Hastuti dan Susilo, 2007). Kondisi pertemuan kedua lempeng ini mempengaruhi kondisi permukaan bumi sehingga Kabupaten Temanggung didominasi oleh bentuk lahan asal vulkanik.

Tabel 3

Luas bentuk lahan Kabupaten Temanggung

\begin{tabular}{lllll}
\hline No & Bentuk lahan & Kode & Luas $\left(\mathrm{Km}^{2}\right)$ & Persentase \\
\hline 1 & Kerucut gunung api & V2 & 5,85 & 0,6 \\
\hline 2 & Lereng tengah-atas gunung api & V4 & 205,38 & 23,8 \\
\hline 3 & Kaki gunung api & V6 & 264,2 & 30,6 \\
\hline 4 & Padang lahar & V11 & 182,36 & 21,1 \\
\hline 5 & Berombak-berguling & S1 & 116,7 & 13,5 \\
\hline 6 & Berguling-berbukit & S3 & 54,34 & 6,29 \\
\hline 7 & Cuesta & $\mathrm{S} 6$ & 15,21 & 1,76 \\
\hline 8 & Hogback & $\mathrm{S} 7$ & 5,52 & 0,64 \\
\hline 9 & Graben & $\mathrm{S} 13$ & 6,75 & 0,78 \\
\hline 10 & Horst & $\mathrm{S} 14$ & 8,03 & 0,93 \\
\hline 11 & Total & & 864,34 & 100 \\
\hline
\end{tabular}

Sumber: Hasil pengolahan citra Landsat 8 


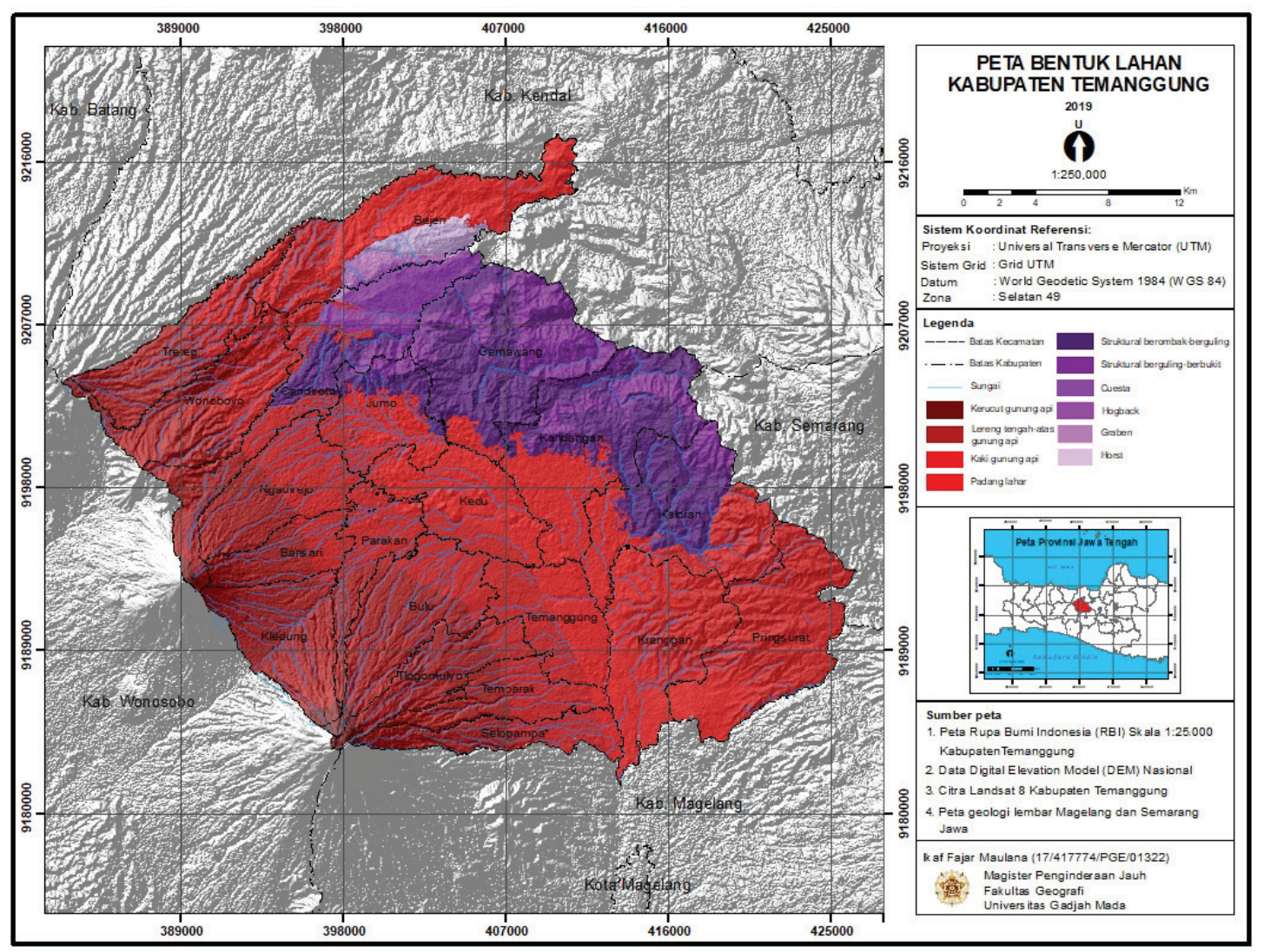

Gambar 7

Peta bentuk lahan Kabupaten Temanggung tahun 2019

Sumber: Hasil Pengolahan Citra Digital (2019)

\section{Peta tekstur tanah}

Informasi tekstur tanah diturunkan dari beberapa informasi seperti bentuk lahan, geologi/ batuan, kemiringan lereng, penutup lahan, dan pola aliran sungai. Beberapa parameter tersebut membantu untuk mempermudah proses interpretasi tekstur tanah dengan menggunakan penginderaan jauh. Hasil interpretasi tekstur tanah yang diturunkan dari beberapa parameter perlu dilakukan proses validasi dengan data tekstur tanah secara aktual. Tekstur tanah yang berada di lapangan dilakukan uji kualitatif maupun kuantitatif untuk mengenali kategori tekstur tanahnya. Uji tekstur tanah secara kualitatif yakni pengenalan kategori tekstur tanah berdasarkan indera peraba, sedangkan uji tekstur tanah secara kuantitatif merupakan pengenalan kategori tekstur tanah dari hasil uji laboratorium metode Hydrometer. Data tekstur tanah lapangan sebagai referensi untuk uji akurasi peta tekstur tanah hasil interpretasi visual. Hasil uji akurasi menghasilkan nilai akurasi peta tekstur tanah Kabupaten Temanggung sebesar $62,16 \%$.

Hasil interpretasi tekstur tanah mengindikasikan bahwasanya lahan pertanian di Kabupaten Temanggung didominasi oleh lempung berliat dengan persentase sebesar $38,08 \%$. Sebagian besar wilayah dengan tekstur tanah lempung berliat terletak pada bagian timur Kabupaten Temanggung. Persentase terbesar kedua yakni lempung berpasir dengan persentase sebesar 37,5\% yang sebagian besar terletak pada bagian tengah Kabupaten Temanggung. Persentase terendah yakni lempung berdebu dengan persentase sebesar $24,42 \%$ atau luas sebesar $211,11 \mathrm{~km}^{2}$ (Tabel 4). Sebaran tekstur tanah lempung berdebu terletak pada bagian barat Kabupaten Temanggung tepatnya di lereng Gunung Sumbing dan Sindoro (Gambar 7). 
IKAF FAJAR MAULANA, SUDARYANTO, DAN RETNADI HERU JATMIKO * IDENTIFIKASI SEBARAN KERENTANAN KEKERINGAN PERTANIAN MENGGUNAKAN ANALYTICAL ...

Tabel 4

Luas tekstur tanah Kabupaten Temanggung tahun 2019

\begin{tabular}{llcl}
\hline No & Tekstur tanah & $\begin{array}{c}\text { Luas } \\
\left(\mathbf{K m}^{\mathbf{2}} \mathbf{)}\right.\end{array}$ & $\begin{array}{c}\text { Persentase } \\
\mathbf{( \% )}\end{array}$ \\
\hline 1 & Lempung berpasir & 324,12 & 37,5 \\
\hline 2 & Lempung berdebu & 211,11 & 24,42 \\
\hline 3 & Lempung berliat & 329,11 & 38,08 \\
\hline & Total & 864,34 & 100 \\
\hline
\end{tabular}

Sumber: Hasil pengolahan citra Landsat 8

\section{Sebaran kerentanan kekeringan pertanian berdasarkan Analytical hierarchy process (AHP)}

Lahan pertanian di Kabupaten Temanggung yang rentan dan sangat rentan terhadap kekeringan pertanian seluas 86,2 $\mathrm{km}^{2}$ dan $74,14 \mathrm{~km}^{2}$. Beberapa kecamatan yang rentan terhadap kekeringan pertanian terletak pada bagian barat Kabupaten Temanggung seperti Kecamatan Selopampa, Tembarak, Tlogomulyo, Bulu, Parakan, Kledung, Bansari,

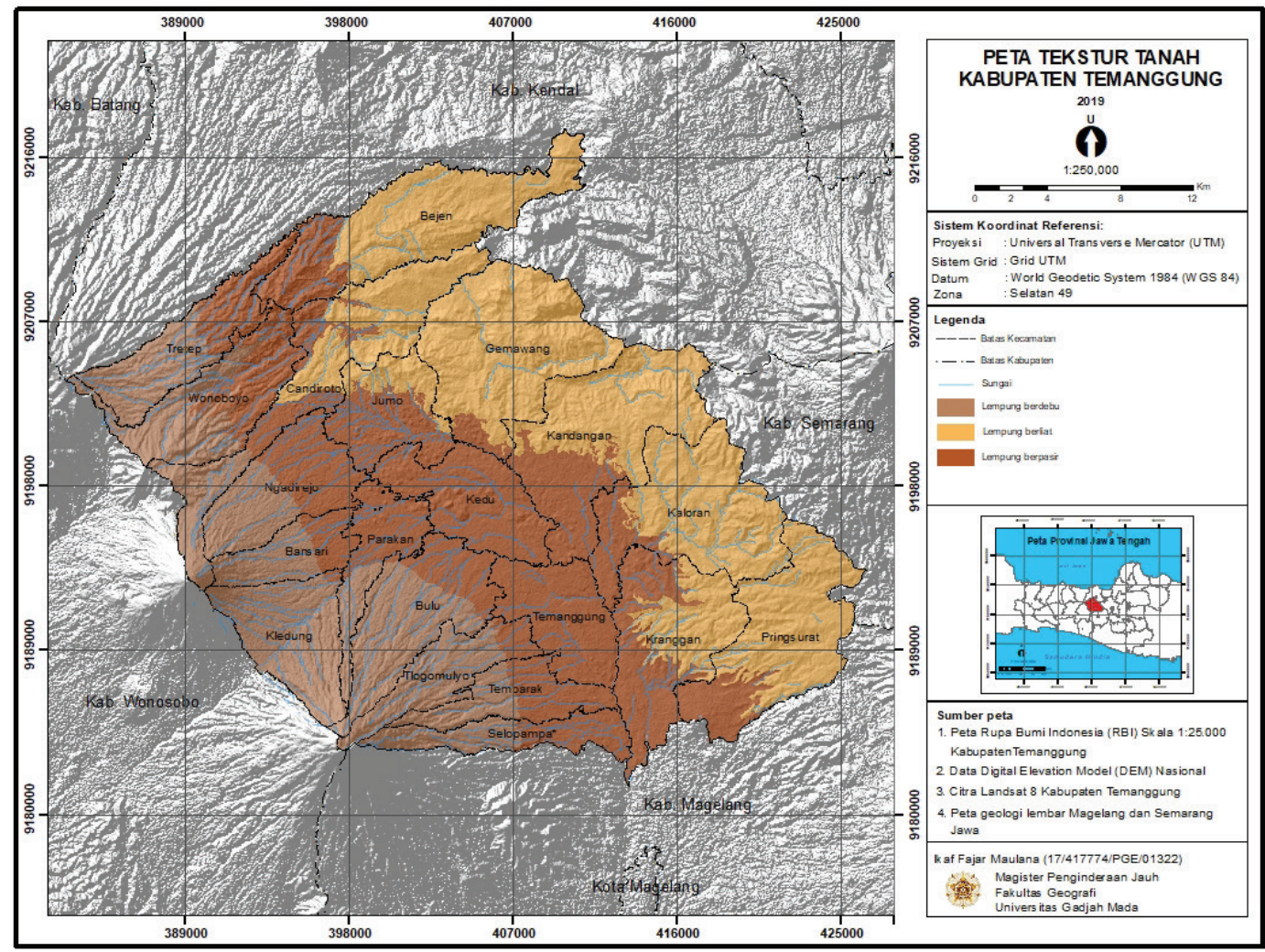

Gambar 8

Peta tekstur tanah Kabupaten Temanggung tahun 2019

Sumber: Hasil Pengolahan Citra Digital (2019)

Ngadirejo, Candiroto, Wonoboyo, dan Tretep. Karakteristik geografi pada beberapa kecamatan tersebut sebagian besar terletak pada lahan dengan tanaman semusim lahan kering. Karakteristik tekstur tanah pada wilayah tersebut yakni lempung berdebu. Selain itu, wilayah yang rentan kekeringan pertanian terletak pada kemiringan lereng agak curam sampai sangat curam.

Lahan pertanian dengan tanaman semusim lahan kering memiliki persentase tutupan vegetasi yang sangat rendah sehingga radiasi matahari akan secara langsung kontak dengan permukaan tanah. Hal ini akan menyebabkan penurunan kelembaban tanahnya karena mengalami penguapan (Wicahyani et al, 2014). Hal ini akan menyebabkan kekeringan pada lahan pertanian tersebut karena ketersediaan air pada permukaan tanah secara cepat mengalami penguapan. Selain itu, kemiringan lereng merupakan faktor yang berpengaruh terhadap kekeringan pertanian. Hal ini berkaitan secara 
langsung dengan tingkat run off dan infiltrasi (Andrian et al, 2014). Lahan pertanian yang rentan terhadap kekeringan pertanian terdapat pada kemiringan lereng agak curam sampai sangat curam sehingga air yang diserap kedalam tanah sangat sedikit. Hal ini menyebabkan ketersediaan air dalam tanah rendah sehingga tidak mampu memenuhi kebutuhan air untuk tanaman.

Pada bagian tengah Kabupaten Temanggung seperti Kecamatan Selopampa, Tembarak, Tlogomulyo, Bulu, Parakan, Bansari, Ngadirejo, Candiroto, Wonoboyo, Jumo, Kedu, dan Kandangan tergolong dalam kategori kerentanan sedang. Luas lahan pertanian dalam kategori kerentanan sedang yakni sebesar 208,21 Km². Karakteristik geografi lahan pertanian pada kerentanan sedang sebagian besar terletak pada tutupan lahan dengan tanaman semusim lahan basah, tekstur tanahnya yakni lempung berpasir, dan kemiringan lerengnya datar sampai landai.

Pada bagian tengah Kabupaten Temanggung masuk dalam kategori kerentanan sedang. Hal ini dikarenakan karakteristik geografi pada bagian tengah Kabupaten Temanggung mampu mendorong kekeringan pertanian dan tidak mampu mendorong terjadinya kekeringan pertanian. Faktor yang mendorong terjadinya kekeringan pertanian yakni faktor tutupan lahan. Faktor tutupan lahan dengan tanaman semusim lahan basah mampu menyebabkan penguapan pada lahan tersebut sangat tinggi karena secara langsung radiasi matahari akan kontak langsung dengan permukaan. Selain itu, faktor lain yang berpengaruh yakni kondisi tekstur tanahnya berupa lempung berpasir. Tekstur tanah ini menyebabkan potensi kekeringan karena tekstur tanah ini memiliki daya ikat terhadap air yang sangat rendah dan kemampuan resapan yang tinggi sehingga ketersediaan air untuk tanaman sangat rendah (Jamulya dan Sunarto, 1991). Faktor yang mendorong tidak terjadi kekeringan pertanian pada bagian tengah Kabupaten Temanggung karena didominasi pada kemiringan yang datar sampai landai. Hal ini yang menyebabkan kondisi run off sangat rendah dan infiltrasi sangat tinggi sehingga potensi air masuk kedalam tanah akan semakin besar.

Pada bagian timur Kabupaten Temanggung dalam kategori tidak rentan sampai sangat tidak rentan terhadap kekeringan pertanian. Luas lahan pertanian yang tidak rentan sampai sangat tidak rentan terhadap kekeringan yakni sebesar 128,15 $\mathrm{Km}^{2}$ dan 267,33 Km². Karakteristik geografi pada lahan yang tidak rentan terhadap kekeringan yakni sebagian besar terletak pada kebun dan tanaman campuran. Tekstur tanah yang mendominasi pada wilayah tersebut yakni lempung berliat serta kemiringan lereng terletak pada kemiringan agak curam sampai sangat curam.

Pada bagian timur Kabupaten Temanggung didominasi dengan tutupan lahan kebun dan tanaman campuran yang memiliki persentase kerapatan vegetasi yang cukup tinggi. Hal ini menyebabkan radiasi matahari tidak secara langsung kontak dengan permukaan tanah sehingga kelembaban pada tanah tersebut tetap tinggi. Selain itu, pada wilayah ini memiliki tekstur tanah yang mampu mengikat air lebih baik sehingga potensi kekeringan pada lahan tersebut rendah pada wilayah ini, sedangkan faktor kemiringan lereng tidak memiliki pengaruh yang signifikan terhadap kekeringan pertanian di bagian timur Kabupaten Temanggung.

Tabel 5

Luas kerentanan kekeringan pertanian

Kabupaten Temanggung tahun 2019

\begin{tabular}{llll}
\hline No & \multicolumn{1}{c}{ Kategori } & Luas $\left.\mathbf{( k m}^{2}\right)$ & Persentase \\
\hline 1 & $\begin{array}{l}\text { Sangat rentan } \\
\text { kekeringan } \\
\text { pertanian }\end{array}$ & 74,14 & 241,08 \\
\hline 2 & $\begin{array}{l}\text { Rentan } \\
\text { kekeringan } \\
\text { pertanian }\end{array}$ & 86,2 & 9,97 \\
\hline 3 & $\begin{array}{l}\text { Sedang } \\
\text { kekeringan } \\
\text { pertanian }\end{array}$ & 208,21 & 24,09 \\
\hline 4 & $\begin{array}{l}\text { Tidak rentan } \\
\text { kekeringan } \\
\text { pertanian }\end{array}$ & 128,15 & 14,83 \\
\hline 5 & $\begin{array}{l}\text { Sangat } \\
\text { tidak rentan } \\
\text { kekeringan } \\
\text { pertanian }\end{array}$ & 267,33 & 11,61 \\
\hline 6 & Non pertanian & 100,31 & 6,06 \\
\hline 7 & Total & 864,34 & 100 \\
\hline
\end{tabular}

Sumber: Hasil Analisis dan Pengolahan Citra Digital (2019) 


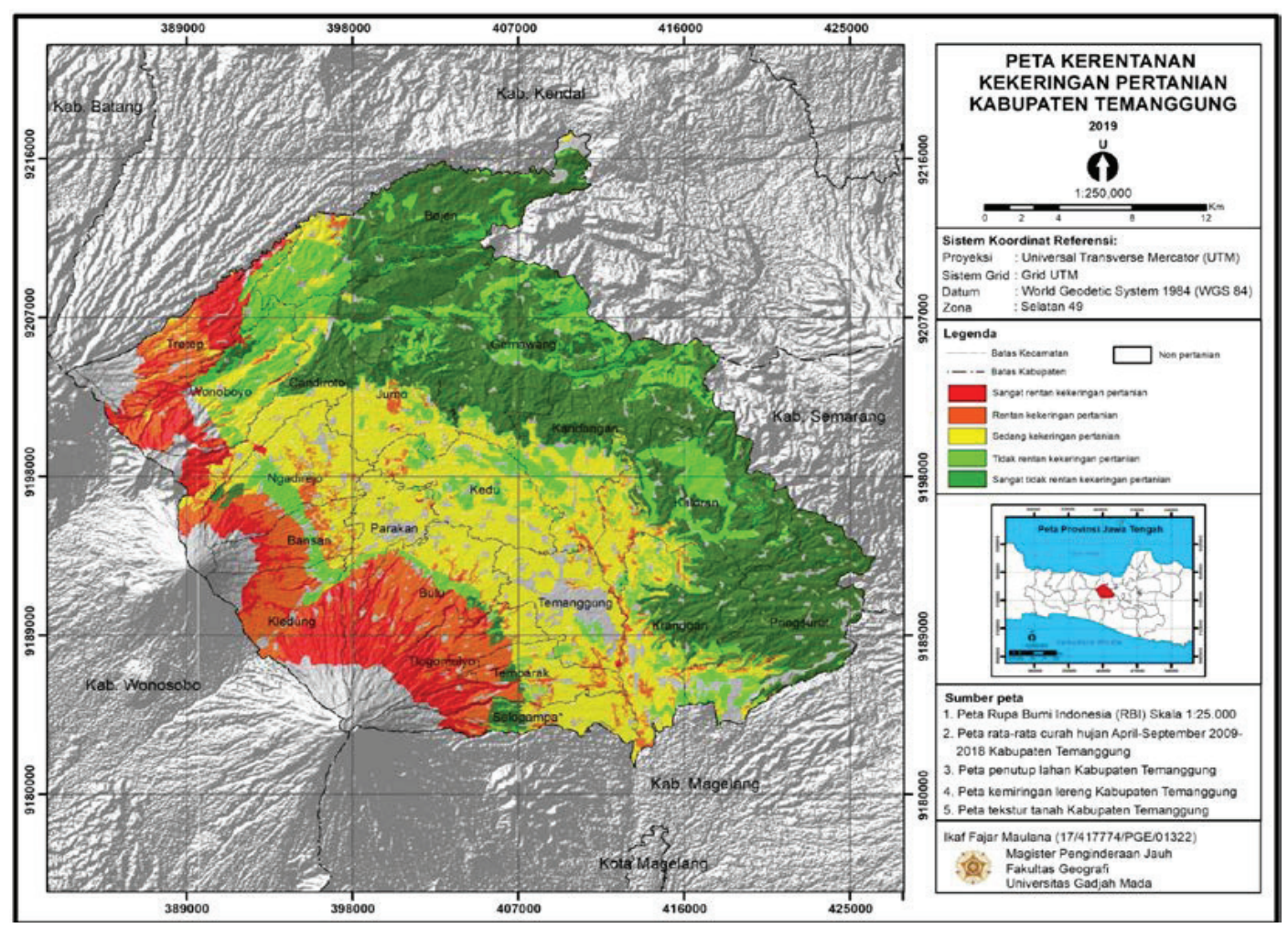

Gambar 9

Peta kerentanan kekeringan pertanian di Kabupaten Temanggung tahun 2019 Sumber: Hasil Pengolahan Citra Digital (2019)

\section{Hubungan parameter terhadap kerentanan kekeringan pertanian berdasarkan Analytical hierarchy process (AHP)}

Hasil kuisioner menghasilkan informasi bahwasanya faktor utama kekeringan pertanian di Kabupaten Temanggung dipengaruhi oleh curah hujan dengan nilai bobot sebesar 0,406. Faktor yang kedua yang menentukan kekeringan pertanian di Kabupaten Temanggung yakni penutup lahan dengan nilai bobot sebesar 0,263. Faktor yang ketiga yakni tekstur tanah dengan bobot sebesar 0,177, sedangkan faktor kemiringan lereng memiliki pengaruh yang sangat kecil terhadap kekeringan pertanian di Kabupaten Temanggung dengan nilai bobot sebesar 0,154 (Tabel 6).

Tabel 6

Harkat dan bobot parameter kerentanan kekeringan pertanian di Kabupaten Temanggung

\begin{tabular}{|c|c|c|c|c|c|}
\hline No & Parameter & Kategori & Harkat & Bobot & (Harkat*Bobot) \\
\hline \multirow[t]{9}{*}{1} & Curah hujan & $0-20$ & 0,255 & \multirow{9}{*}{0,406} & 0,1035 \\
\hline & & $20-50$ & 0,21 & & 0,0853 \\
\hline & & $50-100$ & 0,168 & & 0,0682 \\
\hline & & $100-150$ & 0,133 & & 0,0540 \\
\hline & & $150-200$ & 0,089 & & 0,0361 \\
\hline & & $200-300$ & 0,059 & & 0,0240 \\
\hline & & $300-400$ & 0,039 & & 0,0158 \\
\hline & & $400-500$ & 0,026 & & 0,0106 \\
\hline & & $>500$ & 0,021 & & 0,0085 \\
\hline
\end{tabular}




\begin{tabular}{|c|c|c|c|c|c|}
\hline No & Parameter & Kategori & Harkat & Bobot & (Harkat*Bobot) \\
\hline \multirow[t]{4}{*}{2} & \multirow[t]{4}{*}{ Penutup lahan } & Kebun dan tanaman campuran & 0,071 & \multirow{4}{*}{0,263} & 0,0187 \\
\hline & & Perkebunan tanaman kayu keras & 0,049 & & 0,0129 \\
\hline & & Tanaman semusim lahan basah & 0,268 & & 0,0705 \\
\hline & & Tanaman semusim lahan kering & 0,612 & & 0,1610 \\
\hline \multirow[t]{5}{*}{3} & \multirow[t]{5}{*}{ Kemiringan lereng } & Datar & 0,037 & \multirow{5}{*}{0,154} & 0,0057 \\
\hline & & Landai & 0,058 & & 0,0089 \\
\hline & & Agak curam & 0,143 & & 0,0220 \\
\hline & & Curam & 0,282 & & 0,0434 \\
\hline & & Sangat curam & 0,48 & & 0,0739 \\
\hline \multirow[t]{3}{*}{4} & \multirow[t]{3}{*}{ Tekstur tanah } & Lempung berliat & 0,065 & \multirow{3}{*}{0,177} & 0,0115 \\
\hline & & Lempung berdebu & 0,242 & & 0,0428 \\
\hline & & Lempung berpasir & 0,693 & & 0,1227 \\
\hline
\end{tabular}

Sumber: Hasil kuisioner BPBD Kabupaten Temanggung (2020)

Selain bobot parameter, bobot tiap kategori diperlukan untuk membangun model kerentanan kekeringan pertanian di Kabupaten Temanggung. Kategori yang menentukan kekeringan pertanian pada parameter curah hujan yakni kondisi sangat kering. Kondisi sangat kering yakni ketika selama tiga bulan terjadi penurunan curah hujan yang sangat drastis atau jumlah evaporasi lebih besar dibandingkan dengan curah hujan sehingga akan berdampak pada penurunan jumlah air untuk pertanian (Wang et al, 2016). Semakin tinggi curah hujan pada suatu wilayah maka pengaruhnya semakin rendah terhadap kekeringan pertanian di Kabupaten Temanggung. Hal ini dikarenakan suplai air untuk pertanian mampu untuk menyuplai dalam musim kemarau sehingga kekeringan pertanian dapat diantisipasi.

Pada parameter kemiringan lereng, kategori lereng yang memiliki kemiringan yang agak curam sampai sangat curam memiliki pengaruh terhadap kekeringan pertanian lebih tinggi dibandingkan dengan lereng yang datar sampai landai. Hal ini memiliki keterkaitan dengan penentu tingkat run off maupun infiltrasi (Akbarimehr dan Naghdi, 2012). Semakin besar sudut lereng maka tingkat run off akan tinggi, sedangkan infiltrasi akan rendah, hal ini yang menyebabkan lahan pertanian pada kemiringan tersebut sangat mudah terjadi kekeringan. Berbeda halnya dengan sudut lereng yang kecil maka tingkat run off akan kecil sehingga infiltrasi akan tinggi karena gaya gravitasi, kondisi seperti ini menjadikan kelembaban tanah untuk lahan pertanian akan tetap terjaga.

Pada parameter tekstur tanah, tekstur yang paling berpengaruh pada kekeringan pertanian di Kabupaten Temanggung yakni lempung berpasir apabila dibandingkan dengan lempung berdebu dan lempung berliat. Hal ini berkaitan dengan ukuran partikel tanahnya yang mempengaruhi daya serap maupun ikat terhadap air (Intara et al, 2011). Semakin rendah daya serapnya dan rendah daya ikatnya maka akan berpengaruh terhadap kekeringan pada lahan pertanian. Lempung berpasir memiliki daya serap yang tinggi akan tetapi memiliki daya ikat yang rendah maka akan rentan terhadap kekeringan, sedangkan lempung berliat memiliki daya ikat yang tinggi maka pengaruh terhadap kekeringan pertanian akan lebih kecil.

Pada parameter penutup lahan, lahan pertanian dengan tanaman semusim lahan kering memiliki dampak besar terhadap kekeringan pertanian di Kabupaten Temanggung dengan nilai harkat 0,612, sedangkan penutup lahan yang memiliki dampak yang kecil terhadap kekeringan pertanian di Kabupaten Temanggung yakni perkebunan dengan tanaman berkayu keras dengan nilai bobot sebesar 0,049 dan kebun 
campuran dengan bobot 0,071. Penutup lahan dengan tanaman semusim lahan kering memiliki penguapan dan run off yang tinggi karena penutup lahan ini karakteristik tanamannya memiliki vegetasi yang sedikit sehingga menyebabkan kekeringan pertanian (Chen et al, 2011). Hal ini berbeda dengan perkebunan dengan tanaman kayu keras dan kebun tanaman campuran yang didominasi dengan tanaman berkayu sehingga radiasi matahari tidak kontak langsung dengan tanah sehingga penguapan akan lebih rendah. Selain itu, keberadaan tanaman berkayu akan mampu mengikat air dibandingkan dengan tutupan lahan yang sedikit tanaman.

\section{SIMPULAN}

Lahan pertanian yang rentan terhadap kekeringan pertanian terdapat di bagian barat Kabupaten Temanggung. Luas lahan pertanian yang rentan kekeringan sebesar 160,34 km² atau $18,55 \%$ dari seluruh luas Kabupaten Temanggung. Lahan pertanian yang rentan terhadap kekeringan memiliki curah hujan rata-rata $100-200 \mathrm{~mm}$ pada musim kemarau dan sebagian besar tutupan lahannya yakni tanaman semusim lahan kering. Karakteristik tekstur tanah pada lahan tersebut yakni lempung berdebu dengan kemiringan lereng agak curam sampai sangat curam.

Faktor yang sangat berpengaruh besar terhadap kekeringan pertanian di Kabupaten Temanggung yakni curah hujan. Hal ini berkaitan dengan suplai untuk kebutuhan air tanaman saat masa tanam. Semakin rendah curah hujan maka semakin rentan terhadap kekeringan pertanian karena suplai air untuk tanaman mengalami penurunan karena tidak diimbangi dengan kesediaan air.

\section{DAFTAR PUSTAKA}

Akbarimehr, M; Naghdi, R. 2012. “Assessing the Relationship of Slope and Runoff Volume on Skid Trails (Case Study: Nav 3 District)." Journal of Forest Science 58(8): 357-62.

Andrian; Supriadi; Marpaung, Purba. 2014. "Pengaruh Ketinggian Tempat Dan Kemiringan Lereng Terhadap
Produksi Karet (Hevea Brasiliensis Muell. Arg.) Di Kebun Hapesong PTPN III Tapanuli Selatan." Jurnal Agroekoteknologi Universitas Sumatera Utara 2(3): 981-89.

Arjasakusuma, Sanjiwana; Yamaguchi, Yasushi; Hirano, Yasuhiro; Zhou, Xiang. 2018. "ENSO-and RainfallSensitive Vegetation Regions in Indonesia as Identified from MultiSensor Remote Sensing Data." ISPRS International Journal of GeoInformation 7(3): 1-19.

Arnoldussen, Ludger. 2013. Severe Weather in Eastern Asia (Perils, Risks, Insurance). Munchen: Munich RE.

Badan Nasional Penanggulangan Bencana. 2018. "Data Informasi Bencana Indonesia (DIBI)." http:/ / dibi.bnpb. go.id/. 13 Desember 2018 (15.32)

Badan Pusat Statistik. 2018. Kabupaten Temanggung Dalam Angka 2018. Kabupaten Temanggung: BPS Kabupaten Temanggung.

Chen, Jingwen; Yu, Zhongbo; Zhu, Yonghua; Yang, Chuanguo. 2011. "Relationship between Land Use and Evapotranspiration-a Case Study of the Wudaogou Area in Huaihe River Basin." Procedia Environmental Sciences 10(PART A): 491-98.

Hastuti, Endang Wiwik Dyah;, and Budhi Kuswan Susilo. 2007. “Tektonik Lempeng Dan Bencana Geologi Di Sumatera Dan Jawa." In Kongres Ilmu Pengetahuan Wilayah Indonesia Bagian Barat, , A.4.1-A.4.9.

Intara, Yazid Ismi; Sapei, Asep; Erizal; Sembiring, Namaken, Djoefrie, Bintoro. 2011. "Pengaruh Pemberian Bahan Organik Pada Tanah Liat Dan Lempung Berliat Terhadap Kemampuan Mengikat Air." Jurnal ilmu pertanian Indonesia 16(2): 130-35.

Jamulya; Sunarto. 1991. Evaluasi Sumberdaya Lahan (Kemampuan Lahan). 
Yogyakarta: Universitas Gadjah Mada.

Mannocchi, F; Todisco, F; Vergni, L. 2004. "Agricultural Drought: Indices, Definition and Analysis." In Proceedings of the UNESCO/IAHS/ IWHA Symposium, , 246-54.

McKee, T; Doesken, Nolan J; Kleist, J. 1993. "The Relationshop of Drought Frequency and Duration to Time Scales." Eighth Conference on Applied Climatology, 818-24.

Riphah, Umair Shahzad. 2015. “Global Warming: Causes, Effects and Solutions." Durreesamin Journal 1(4): $1-7$.
Saaty, Thomas L. 2008. "Decision Making with the Analytic Hierarchy Process." International Journal Services Sciences 1(1): 83-98.

Wang,Wen;Ertsen, MauritsW;Svoboda, Mark D; Hafeez, M. 2016. "Propagation of Drought: From Meteorological Drought to Agricultural and Hydrological Drought." Advances in Meteorology 2016(March): 1-5.

Wicahyani, Suksesi; Sasongko, Setia Budi; Izzati; Munifatul. 2014. "Jurnal Geografi Media Informasi Pengembangan Ilmu Dan Profesi Kegeografian Sebagai Deskripsi Untuk Suhu Yang Terjadi Di." Jurnal Geografi 11(2): 196-205.

Zuidam, Van. 1983. Guide to Geomorphologic Aerial Photographic Interpretation and Mapping. Enschede: ITC. 